\title{
A Review of Antoine Traisnel, Capture: American Pursuits and the Making of the New Animal Condition. Minneapolis, $\mathrm{MN}$ and London: University of Minnesota Press, 2020, 358 pages, ISBN 978-1-5179- 0964-2 (pb), hardcover 108 \$, paperback 27 \$
}

\author{
Michael Fuchs
}

University of Oldenburg

E-mail: michael.fuchs@uol.de

In his volume Kunstformen der Natur (Artforms of Nature, 1899-1904), Ernst Haeckel, who was key to popularizing Charles Darwin's ideas in Germany, sought to 'bring to light the hidden treasures [of Nature]' and to 'make them accessible to a larger group of people who appreciate art and nature'. ${ }^{1}$ When leafing through Kunstformen der Natur, readers find illustrations of boxfishes, bristle worms, siphonophores, nepenthes, crustaceans, slime moulds, and other creatures that readers may not necessarily think of as 'beautiful' or as evidence of 'Nature's art'. Nevertheless, Adolf Glitsch's lithographs, which were based on Haeckel's sketches and drawings, arouse one's curiosity due to their mysterious nature or appeal to one's aesthetic sensibilities. Indeed, the plates alternate, seemingly randomly, between ordered sequences of individual representatives of species and what may be likened to backgrounds of natural history dioramas. These two different visual approaches bring together the central premise in Haeckel's natural philosophy: beauty and truth are two sides of the same coin. The sciences (represented by the ordered sequences of species, which emphasize symmetry ${ }^{2}$ ) may uncover certain aspects of nature and nature's laws, but art has the potential to reveal larger truths. ${ }^{3}$

While most of the illustrations in Kunstformen der Natur focus on marine lifeforms and species inhabiting Europe, northern Africa, and southern Asia, the tenth and final - volume includes a plate that displays a family native to the New World: hummingbirds. Haeckel explained that the birds' 'very particular aesthetic allure and their poetic romanticization' is due to the 'combination of their delicate bodies and their gorgeous plumage with their extraordinary gracefulness and the speed of their

\footnotetext{
${ }^{1}$ Ernst Haeckel, Kunstformen der Natur, vol. 1 (Leipzig: Verlag des Bibliographischen Instituts, 1899), n. p., my translation. The title of Haeckel's book is usually translated as 'art forms in nature'. While the German genitive 'der' may point at the elision of either 'in' and 'von' in this case - that is, it may be 'in nature' and 'of Nature', I believe 'of' to be the more appropriate preposition. Haeckel's preface opens: 'In her womb, Nature produces an inexhaustible abundance of wonderful creature, whose beauty and variety far exceed any and all human artforms', which emphasizes the notion of art produced by Nature, not only found in nature.

2 As Olaf Breidbach explains, Haeckel believed that all lifeforms 'are subjected to principles of symmetry'. Olaf Breidbach, 'Kurze Anleitung zum Bildgebrauch', in Kunstformen der Natur | Kunstformen aus dem Meer, by Ernst Haeckel, ed. Olaf Breidbach (Munich: Prestel Verlag, 2012), 105, my translation.

${ }^{3}$ For more on Haeckel's philosophy, see, for example, Bernhard Kleeberg, Theophysis: Ernst Haeckels Philosophie des Naturganzen (Vienna: Böhlau Verlag, 2005).
} 
movements'. ${ }^{4}$ For the riveting cover of Capture, designer Sandra Friesen extracted eleven of the twelve species collected in the illustration (the white-booted racket-tail was removed to make room for the book's subtitle and the author's name), placed them on a black background, and interweaved the birds with the letters CAPTURE. While the original illustration assembled birds from all across the Americas, ${ }^{5}$ it tried to erase the traces of its human architects - Haeckel meant to showcase Nature's art, after all. The cover of Capture, on the other hand, highlights its constructedness, as the birds seem to be as much trapped in the symbolic cage composed of the letters as in the aesthetic conventions of the late nineteenth/early twentieth century.

Thus, the stunning and semantically loaded cover (and lines extracted from Jacques Prévert's 'Pour faire le portrait d'un oiseau' [1945], which greet readers after the copyright page) guides readers into Antoine Traisnel's monograph, introducing some of the ideas that will undergird the study. Indeed, Traisnel's argument centres on how, by the end of the nineteenth century, animals became archived (i.e., written about, drawn, photographed, filmed, taxidermied, etc.), 'ironically, in order to preserve and study their liveness' (2). Traisnel acknowledges that this idea draws on John Berger's observation that industrialization led to the increasing replacement of physical wildlife encounters with mediated ones and Akira Mizuta Lippit's notion that, by the early twentieth century, '[a]nimals had found a proper habitat or world in the recording devices of the technological media'. ${ }^{6}$ However, Traisnel's book expertly expands on these ideas to trace 'a shift from the hunt regime to the capture regime' (2) in nineteenth-century America. This transformation from the actual hunt to the (purportedly) bloodless apprehension of animals through representational technologies is accompanied by a shift from understanding animals as individual specimens to trying to extract 'something presumably inherent to all animals: vitality, motion, states of change' (2) from animals. Moby-Dick (1851) could be said to encapsulate the transition from hunt to capture, as the novel does not only tell a story about a ship hunting whales and its captain chasing a very specific white whale; in addition, the narrator's various ruminations about whale fossils, cetology, the whale's physiology, etc. indicate the apparent desire to pin down the essence of whale-ness. Once the essence of the animal is defined (which Ahab may do, but Ishmael effectively refuses to), 'capture makes the subjection of that which is preyed upon appear predetermined, even preaccomplished [...]. Under capture, animals are assumed already at hand but fundamentally dilocated' (10). Accordingly, '[c]apture names the paradoxical regime of vision by which animals came to be seen as at once unknowable yet understood in advance - a frame by which we continue to encounter animals today' (29).

\footnotetext{
${ }^{4}$ Ernst Haeckel, Kunstformen der Natur, vol. 10 (Leipzig: Verlag des Bibliographischen Instituts, 1904), n. p. Wikimedia has a digital version of the plate, available at https://commons.wikimedia.org/wiki/File:Haeckel_Trochilidae.jpg [accessed 20 November 2021]. ${ }^{5}$ In view of Capture's focus on the United States, it seems worth mentioning that, according to Haeckel's description, the ruby-throated hummingbird is the only species depicted in the illustration native to the United States. He likely adapted this idea from the tenth edition of Carl Linnaeus's Systema naturae (1758), which, in turn, was based on Mark Catesby's The Natural History of Carolina, Florida and the Bahama Islands (1729) and George Edwards's A Natural History of Uncommon Birds (1743). However, the ruby-throated hummingbird is also native to Central America and, in fact, migrates to northern parts of North America to breed.

${ }^{6}$ Akira Mizuta Lippit, Electric Animal: Toward a Rhetoric of Wildlife (Minneapolis, MN and London: University of Minnesota Press, 2000), 25.
} 
Michel Foucault's concept of biopower underpins Capture's discussion of how animals became subjected to this very power, as Traisnel repeatedly emphasizes that the 'new animal condition' of capture is 'inextricable from the making of the new nation' (4) and, as such, coterminous with questions of settler colonialism, ${ }^{7}$ slavery, and biocapitalism. Since Capture is 'a theoretical, literary, and material analysis of the transformation of animal representation in its lasting biopolitical consequences [...] rather than a cultural history' (5), Traisnel's choice of texts is highly selective. In his study, Traisnel draws on key figures in animal studies alongside nineteenth-century writers such as William Apess, scientists and historians of science, and contemporary voices such as Sylvia Wynter and Achille Mbembe to explore five canonical works of nineteenth-century America in an attempt to demonstrate how 'techniques of knowledge and control prototyped through visual and scientific experiments bent on understanding and ordering animal life' (28) epitomize the evolution from the hunt to the capture regime. (One is left wondering whether and how a more diverse cast of characters female authors, ethnic voices, etc. - would have altered Traisnel's narrative.)

Part One of the book, titled 'Last Vestiges of the Hunt', examines two of these iconic works, John James Audubon's Birds of North America (1827-1838), with a particular focus on Golden Eagle, Aquila chrysaetos (1833), and James Fenimore Cooper's The Prairie (1827). Traisnel helpfully opens the chapter on Audubon by repeating a key premise of the book: although hunting 'was rapidly falling out of common practice' in early nineteenth-century North America, it 'did not disappear', but rather transformed into 'a cultural and epistemological logic', as 'animals came to be subjected to increasingly more invasive and furtive forms of knowledge and control' (33). Turning to Audubon's work, Traisnel emphasizes the well-known fact that Audubon hunted and killed birds before drawing them. Audubon thus epitomizes the hunt regime, but his practice of collecting and his goal of creating lifelike images - an impossible task, as Audubon came to understand - anticipated the emergence of the capture regime. While this chapter excellently picks up ideas and concepts outlined in the introduction, Traisnel's discussion of the two versions of Golden Eagle is particularly insightful. ${ }^{8}$ For Traisnel, the removal of the woodsman, who is 'very much alive and active' (43) and who has a dead eagle strapped around his shoulder, ${ }^{9}$ from the folio edition erases a self-reflexive layer that seems to struggle with both Audubon's practices and the image's implied meanings. In the original, there are 'two versions of what appears to be the exact same eagle, simultaneously captured (on the hunter's shoulder) and free (as a bird). The fact that the eagle is at once dead and alive in the picture, like Schrödinger's cat in his box, implicitly correlates the killing of the empirical animal and its transformation into a representative specimen' (43).

\footnotetext{
${ }^{7}$ For example, one may think of the displacement of Indigenous populations and the 'vanishing Indian' archived in stories, photographs, etc. along lines of hunt and capture.

${ }^{8}$ Traisnel claims that 'Golden Eagle is the only painting of Audubon's to include a human character' (43). The original watercolour of the snowy egret (1832; Havell plate no. 242) features a hunter 'who may have been meant to represent the species' greatest enemy', Roberta Olson suggests. Roberta J. M. Olson, 'Highlights from the Watercolors for The Birds of America', in Audubon's Aviary: The Original Watercolors for The Birds of America, ed. Roberta J. M. Olson (New York: New York Historical Society, 2012), 286.

${ }^{9}$ See 'Golden Eagle (Aquila chrysaetos), Havell plate no. 181', Audubon's Watercolors for The Birds of America, New York Historical Society; available at https://www.nyhistory.org/exhibit/golden-eagleaquila-chrysaetos-havell-plate-no-181 [accessed 20 November 2021].
} 
The second chapter, 'Land Speculations', moves to The Prairie, which was published as the third of the Leatherstocking Tales but concludes the story of Natty Bumppo. In Traisnel's reading, the taming of the American wilderness in the early nineteenth century results in the transformation of the American embodiment of the hunter, Natty Bumppo, into a trapper. As hunting thus becomes a relic of the past, the myopic taxonomist Obed Bat emerges. The implied replacement of the hunter by a short-sighted taxonomist, Traisnel argues, is not so much indicative of 'an empirical [... but ...] an epistemological transformation, a transformation in regimes of vision', as the epitome of the colonization of North America must 'disappear for the colonial project to appear complete' (59). The taxonomist's myopia symbolizes 'the calculated act of ignoring possible loss [...] that is built into the venture capital model of settler colonialism' (64). Beyond exploring how taxonomy is framed 'as a highly speculative science' (64) that 'summons into being what it sets out to describe' (66) in the novel, Traisnel skilfully connects the taxonomic drive represented by Obed Bat and the vanishing of the hunter to a metalevel by exploring questions of genre and the disappearance of the romance - that is, the genre in which Cooper was writing. The nostalgia characteristic of the romance thus becomes a swansong to the white hunter and the heyday of colonizing the New World. The problem here is that the puzzle pieces fall into place too easily, as Traisnel fails to address that, for example, Nathaniel Hawthorne, who is discussed in a later chapter, worked in the purportedly vanishing genre of the romance several decades later.

In addition, the Cooper chapter explicitly explores questions of race. Bumppo is figured as the last of his kind and when he 'tries to pass on his legacy to the Pawnee Hard-Heart [...], this does not allow his legacy to live on; instead, it symbolically condemns Hard-Heart to survive spectrally in a time that is no longer his - a time that is neither for Indians nor for hunter' (76). Both the agent of colonialist expansion and the colonized Other subjected to the colonialist project are bound to vanish. Drawing on Walter Benjamin, Traisnel continues this idea in the next chapter, remarking that unlike in the prairie, where people simply disappear, '[i]n cities [...], people disappear as animals' (95). Traisnel's main object of study here is Edgar Allan Poe's 'The Murders in the Rue Morgue' (1841), in which reason, embodied by the hunter-turned-detective, chases down animality, which is both criminalized and associated with racialized Others. Importantly, 'Rue Morgue' showcases the development of the shift from the hunt to the capture regime, since the homicidal orangutan 'is never physically present in the diegesis but exists only through retrospective narration of his owner, the sailor' (119).

Next, Traisnel turns his attention to Hawthorne's The Marble Faun (1860), which was published a few months after Charles Darwin's Origin of the Species (1859). The narrative's main character, Donatello, resists easy categorization, as he/it may or may not be a faun (or some faun-human mix). By reading the novel in view of discourses on taxonomy on both sides of the Atlantic, Traisnel understands The Marble Faun 'as an allegory of taxonomic knowledge' and 'a critical examination of how the newly prominent epistemology of capture altered the view and knowledge of animals' (128). The illegibility of the (part-/non-)faun introduces a temporality different from 'the linearity of progress (Darwin)' and 'the timelessness of the Ideal (Cuvier)' that points at the possibility of 'a knowledge that extends beyond - or rather between - the taxonomic confines of species determination' (152). 
Eadweard Muybridge's iconic series of photographs of horse movements is the focus of the book's fascinating final chapter. Here, Traisnel makes most explicit that technology allows humans to see what cannot be properly perceived by the naked human eye: capture unlinks the sensory perception of an animal from knowledge about animals and sensory perception from time. In particular, Muybridge's fragmentation of a series into discrete units 'invented a way of dissecting the real that made it uniquely vulnerable to capitalist exploitation' (162). While this idea is in line with questions of biocapitalist exploitation and extraction that undergirds the entire book, what may even be more important is that Muybridge's experiments accelerated the dissociation of the animal from its material basis: 'Capture does not simply gather data about people, objects, or place, for what it gathers has no reality prior to the act of capture. The data acquires its ontological dignity as data (as given)' (164-5). The reduction of the animal to data encourages the reproduction of animals for human use and, in the same breath, endorses mass slaughter because as givens, animals are implicated in what Raj Patel and Jason Moore have called the 'cheapening [of] life' typical of the capitalist world ecology. ${ }^{10}$

In the conclusion, Traisnel uses the fate of the passenger pigeon 'as a lens both for apprehending the dire consequences of the rise of capture and for glimpsing the ethical imperative that emerges out of this devastation' (191). Whereas Audubon described a seemingly endless flock of birds that darkened the skies in 1813, in The Pioneers (1823), Cooper warned 'against the transformation of the hunt [...] into something else altogether: an increasingly one-sided, automatic, and indiscriminate slaughter' (192). 'Today', Traisnel stresses, 'a color hologram of [the] taxidermied body [of the last passenger pigeon] rotates in a 360-degree animation on the Smithsonian's website: a flightless pigeon in perpetual motion - a spectral manifestation of the bird caged by the movement of the thaumatrope' (193). From symbol of the abundance of North America in the early 1800 s to thousands of birds being shot indiscriminately in the years that followed to the death of the last wild bird in 1901 to the death of the endling, Martha, at the Cincinnati Zoo in 1914 and Martha's capture in digital technologies, the story of the passenger pigeon perfectly illustrates the transition from the hunt to the capture regime. Unfortunately, Traisnel's intriguing remarks on Martha's transformation into a spectre remain rather brief.

Traisnel concludes the book by suggesting that an understanding of what happened and what continues to happen in the capture regime 'provides the basis for an ethics of life in capture' (193). Drawing on Jakob von Uexküll's concept of Umwelt, Traisnel outlines an 'ethics of cohabitation' (195) that breaks away from our anthropocentric and anthropomorphic ways and embraces 'a new ethics of care and knowledge, as the condition for regarding other animals as well as ourselves' (196). While I fully understand why Traisnel decided to conclude the book by sketching this 'ethics of life in capture' and while Benjamin Hulett, in his insightful review of Capture, is right to point out that Traisnel seems to ignore the interpenetration and mutual co-constitution of different Umwelten in his 'new ethics of care and knowledge', ${ }^{11}$ I am left wondering who the ambiguous - and arguably only potentially inclusive - 'we' of the conclusion might be.

\footnotetext{
${ }^{10}$ Raj Patel and Jason W. Moore, A History of the World in Seven Cheap Things: A Guide to Capitalism, Nature, and the Future of the Planet (Berkeley: University of California Press, 2018), 47.

${ }^{11}$ Benjamin Hulett, Rev. Capture: American Pursuits and the Making of the New Animal Condition, by Antoine Traisnel, Textual Practice, Online First, 9 June 2021.
} 
Capture is a brilliant, thought-provoking book that will not only be of interest to scholars in the fields of animal studies and the environmental humanities, but also nineteenth-century Americanists and, to some extent, visual culture and media studies scholars. Capture is a well-argued and well-written book that, nevertheless, becomes dense and abstract at times. This density is not alleviated by the fact that readers might want to approach the book in a nonlinear fashion, as 80-plus pages of notes are appended to 196 pages of the main study. While, in part, these notes document sources, many of them do, in fact, provide additional information and further elaborate on ideas and discourses introduced in the main part of the text. The extensive bibliography and extremely well-structured index add to the impression of a very well-designed book, as do the more than two dozen grayscale images (about half of which are in the Muybridge chapter) and four colour plates.

Finally, I would be remiss not to mention that Capture was published as a TOME (Toward an Open Monograph Ecosystem) book, which means that an e-version is available through the University of Minnesota Press's open-access library and pdf and epub formats may be freely downloaded through the University of Michigan library. While, of course, free access to scholarship is highly commendable, this is not meant to suggest that potential readers should just download one of the open-access editions not least because the success of open-access monographs is (unfortunately) often measured by how open-access positively impacts sales numbers, but, more importantly, because Capture is worth every penny and more.

\section{Bibliography}

1. Breidbach, Olaf. 'Kurze Anleitung zum Bildgebrauch'. In Kunstformen der Natur | Kunstformen aus dem Meer. By Ernst Haeckel. Edited by Olaf Breidbach. Munich: Prestel Verlag, 2012. 103-15.

2. Haeckel, Ernst. Kunstformen der Natur. Vol. 1. Leipzig: Verlag des Bibliographischen Instituts, 1899.

3. Haeckel, Ernst. Kunstformen der Natur. Vol. 10. Leipzig: Verlag des Bibliographischen Instituts, 1904.

4. Hulett, Benjamin. Rev. Capture: American Pursuits and the Making of the New Animal Condition. By Antoine Traisnel. Textual Practice. Online First. 9 June 2021. Available at DOI 10.1080/0950236X.2021.1936814. Accessed 20 November 2021.

5. Kleeberg, Bernhard. Theophysis: Ernst Haeckels Philosophie des Naturganzen. Vienna: Böhlau Verlag, 2005.

6. Lippit, Akira Mizuta. Electric Animal: Toward a Rhetoric of Wildlife. Minneapolis, MN and London: University of Minnesota Press, 2000.

7. Olson, Roberta J. M. 'Highlights from the Watercolors for The Birds of America'. In Audubon's Aviary: The Original Watercolors for The Birds of America. Edited by Roberta J. M. Olson. New York: New York Historical Society, 2012. 132-367.

8. Patel, Raj, and Jason W. Moore. A History of the World in Seven Cheap Things: A Guide to Capitalism, Nature, and the Future of the Planet. Berkeley: University of California Press, 2018. 